\title{
Calcined Mg-Al hydrotalcites catalyst in the regioselective synthesis of silylated vicinal azidohydrins
}

\author{
Guillermo Negrón, ${ }^{a} *$ Nahí Guerra, ${ }^{a}$ Leticia Lomas, ${ }^{b}$ Rubén Gaviño, ${ }^{c}$ and Jorge Cárdenas ${ }^{c_{*}}$ \\ ${ }^{a}$ Grupo de Química de Materiales and ${ }^{b}$ Departamento de Química, UAM, Av. San Pablo No 180, \\ C.P. 02200, México D.F., México; ${ }^{c}$ Instituto de Química, UNAM, Circuito Exterior, Ciudad \\ Universitaria, Coyoacán 04510, México D.F., México \\ E-mail:gns@correo.azc.uam.mx and rjcp@servidor.unam.mx
}

(received 14 Oct 03; accepted 17 Dec 03; published on the web 31 Dec 03)

\begin{abstract}
Calcined Mg-Al Hydrotalcites $\mathrm{x}=0.20,0.27,0.33$ proved effective catalysts for the oxirane ring opening reaction with trimethylsilyl azide in $n$-heptane at room temperature, yielding quantitative silylated vicinal azidohydrins. The catalyst was reused in several cycles presenting a consistent activity.
\end{abstract}

Keywords: Hydrotalcites, oxirane ring-opening, azidohydrins

\section{Introduction}

Calcined hydrotalcites have been extensively used as solid base catalysts substituting liquid base ones due to the advantages they show in heterogeneous catalysis, i.e. ease of separation from the reaction products, reduction of waste streams, possible regeneration of the catalyst and low cost. ${ }^{1}$ These properties make hydrotalcite-like compounds promising catalysts for commercial use. Recently, modified hydrotalcites have proven active in the coupling of various ketones and aldehydes in base-catalyzed aldol condensation reactions, ${ }^{2-4}$ olefin isomerization, nucleophilic halide exchange, ${ }^{5}$ alkylation of diketones, ${ }^{6}$ epoxidation of activated olefins with hydrogen peroxide, $^{7}$ and Claisen-Schmidt condensation. ${ }^{8}$

Since epoxides serve as fundamental building blocks in organic chemistry, their ring opening reactions are of fundamental interest. Various procedures are available to induce such reactions, some of which allow a selective attack on one of the carbon atoms in the epoxide with steric and, to a certain extent, electronic effects. These effects should be taken into account in order to induce the opening of the ring. ${ }^{9}$

The ring opening reaction of oxiranes with azide compounds presents an effective synthetic route of $\beta$-aminoalcohols, which are very versatile compounds. ${ }^{10}$ Trimethylsilyl azide has been actively employed for this reaction because of its handling properties. ${ }^{11}$ 


\section{Results and Discussion}

As a part of our on going research program on the utilization of hydrotalcite $\mathrm{AlMgCO}_{3}-\mathrm{HT}$ with different $\mathrm{Mg}^{2+} / \mathrm{Al}^{3+}$ ratios in organic reactions, we prepared, characterized, and used calcined $\mathrm{Mg}-\mathrm{Al}$ hydrotalcite to catalyse an oxirane azidation, taking into consideration that the basicity of the calcined hydrotalcite can be modified changing the $\mathrm{Al}$ ratio: $(\mathrm{Al}+\mathrm{Mg})$ ratios (x) of $0.20,0.27$ and 0.33. M. Lakshmi Kantam et al ${ }^{12}$ described the $\mathrm{MgAlCO}_{3}-\mathrm{HT}$ catalyzed ring opening of styrene oxide (1d) with $\mathrm{TMSN}_{3}$ in dry benzene, giving (2-azido-1-phenylethoxy)trimethylsilane (2d) as the only resulting product (62\%). Surprisingly, there was a significant difference in the regioselective composition of the product obtained in the reaction using dry n-heptane instead of benzene. Under these conditions, compound $1 \mathbf{d}$ showed a reversed regioselectivity. The attack of the azide ion on the more substituted $\alpha$-carbon in 1d resulted in $97 \%$ of (2-azido-2phenylethoxy)trimethylsilane (3d) and 3\% of (2-azido-1-phenylethoxy)trimethylsilane (2d). The ring opening of cyclohexene oxide (4) with $\mathrm{TMSN}_{3}$, following the conditions described by $\mathrm{M}$. Lakshmi Kantam, et al, produced trans-(2-azidocyclohexyloxy)trimethylsilane (5) (62\%). This product was obtained in $98 \%$ yield, Scheme 1 . We observed that the $\mathrm{x}$ ratio does not influence the chemical yield since a similar conversion can be achieved using $\mathrm{x}=0.33,0.27$, and 0.20 , furthermore, upon replacing n-heptane with acetonitrile or chloroform a dramatic decrease in the yield was observed. When we used methanol and $\mathrm{N}, \mathrm{N}$-dimethylformamide no reaction was observed.
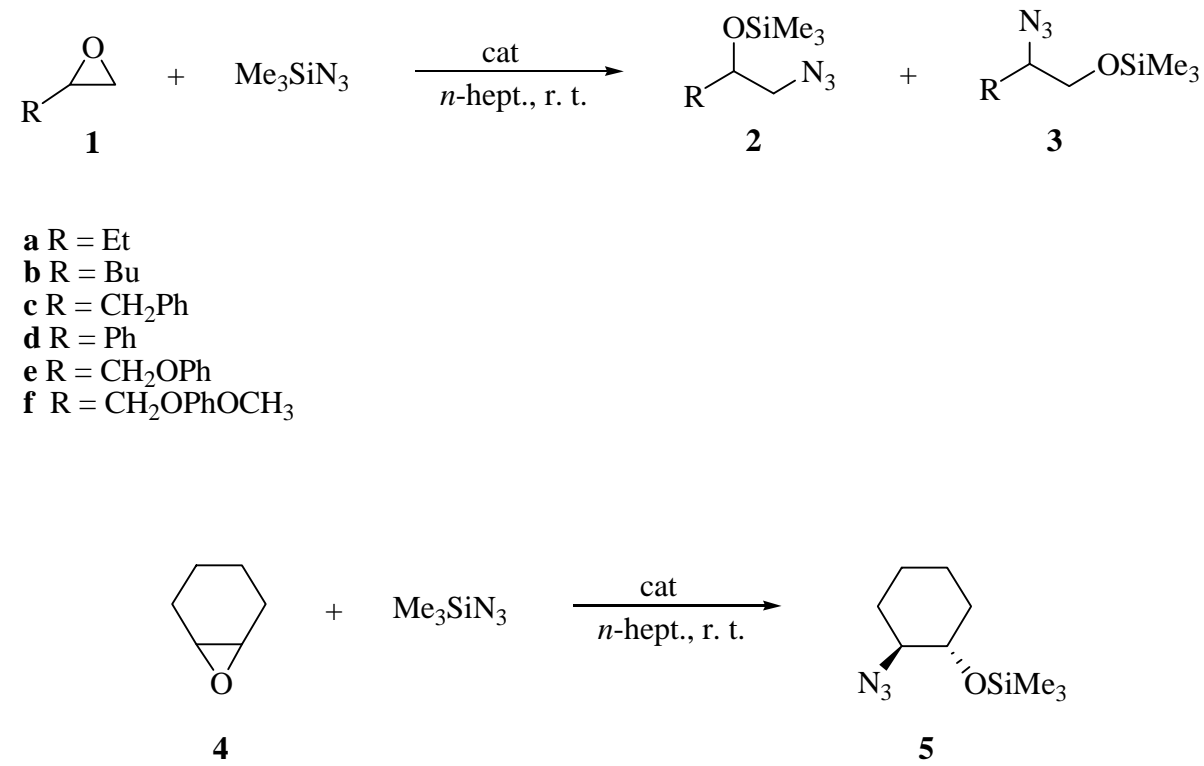

\section{Scheme 1}

We undertook the study of the scope of this reaction due to the potential use of this mild method for the syntheses of azidohydrins. The corresponding $\beta$-azido products were formed in 
quantitative yields. NMR and GC-MS analyses showed that the reactions are highly regioselective. The results are summarized in Table 1.

Table 1. Azidation of various oxiranes catalyzed by $\mathrm{Mg}_{0.687} \mathrm{Al}_{0.313}(\mathrm{OH})_{2}\left(\mathrm{CO}_{3}\right)_{0.16} 0.85 \mathrm{H}_{2} \mathrm{O}$ Using $\mathrm{N}_{3} \mathrm{Si}\left(\mathrm{CH}_{3}\right)_{3}$

\begin{tabular}{|c|c|c|c|}
\hline Entry & Epoxide $^{\mathrm{a}}$ & Products & Yield \\
\hline 1 & & $\mathbf{2 a} / \mathbf{3 a}: 73 / 23$ & $98 \%{ }^{\mathrm{d}}$ \\
\hline 2 & & $\mathbf{2 b} / 3 \mathbf{b}: 78 / 22$ & $98 \%^{\mathrm{d}}$ \\
\hline 3 & & 2c/3c : 98/2 & $99 \%^{\mathrm{d}}$ \\
\hline 4 & & $\mathbf{2 d} / \mathbf{3 d}: 3 / 97$ & $98 \%^{\mathrm{d}}$ \\
\hline 5 & $\mathrm{PhOH}_{2} \mathrm{C}$ & $2 \mathbf{e}$ & $95 \%^{\mathrm{c}}$ \\
\hline 6 & $\mathrm{MeOPhH}_{2} \mathrm{C}^{-}$ & $2 f$ & $95 \%^{\mathrm{c}}$ \\
\hline 7 & & 5 & $98 \%^{\mathrm{c}}$ \\
\hline
\end{tabular}

${ }^{a}$ All the reactions were carried out at room temperature.

${ }^{b}$ Structures and regiochemical ratio determined for the products by proton-NMR and GC-MS.

${ }^{c}$ Yields refers to isolated product.

d Two regioisomers were obtained and the yield refers to both isomers.

\section{Experimental Section}

General Procedures. All the samples of hydrotalcites were characterized by means of powder $\mathrm{XRD}$ with $\mathrm{Cu}-\mathrm{K}_{\alpha}$ radiation, using a Siemens difractometer in the range from 4 to $70^{\circ}$ (2 Theta). FT-IR spectra were recorded on a Nicolet Magna 750 spectrometer, data collection was performed using DRIFT and $\mathrm{KBr}$ disc techniques. DTA and TGA analyses were carried out in a Dupont thermobalance using He flow at a heating rate of $10{ }^{\circ} \mathrm{C} / \mathrm{min}$. Specific surface areas were calculated by $\mathrm{N}_{2}$ adsorption at $75.25 \mathrm{~K}$ (BET method) using a Micromeritics ASAP 2000 instrument. Samples were first degased at $523 \mathrm{~K}$.

The reaction products of the azidation were determined and analyzed by means of a Hewlett Packard GC / MS system 5890/5972 gas chromatograph with an HP-5 column, $70-270^{\circ} \mathrm{C}\left(5^{\circ} \mathrm{C} / \mathrm{min}\right)$, Inj. $250^{\circ} \mathrm{C}$, Det. $280^{\circ} \mathrm{C}$. The final products were determined by 
comparison with the standard mass spectrometry of organic compounds and their fragmentation pattern. ${ }^{1} \mathrm{H}$ NMR spectra were measured on a Varian UNITY-300 spectrometer. Chemical shifts are reported in parts per million $(\delta)$ with tetramethylsilane as internal standard, coupling constants in Hz. Infrared (IR) spectra were recorded on a Nicolet 5-SX FT IR spectrophotometer.

\section{General procedure for the preparation of hydrotalcite catalysts}

$\mathrm{Mg}-\mathrm{Al}$ hydrotalcites with $\mathrm{x}=\mathrm{Al} /(\mathrm{Al}+\mathrm{Mg})$ ratios of $0.20,0.27$ and 0.33 were prepared by coprecipitation following the procedure described by Reichle. ${ }^{13}$ A typical example of the preparation of $\mathrm{Mg}_{0.687} \mathrm{Al}_{0.313}(\mathrm{OH})_{2}\left(\mathrm{CO}_{3}\right)_{0.16} 0.85 \mathrm{H}_{2} \mathrm{O}$ is that in which $\mathrm{Al}\left(\mathrm{NO}_{3}\right)_{3} \cdot 9 \mathrm{H}_{2} 0(0.01 \mathrm{~mol})$ and $\mathrm{Mg}\left(\mathrm{NO}_{3}\right)_{2} \cdot 6 \mathrm{H}_{2} \mathrm{O}(0.05 \mathrm{~mol})$ were dissolved in deionized water $(70 \mathrm{~mL})$. A second deionized water solution $(100 \mathrm{ml})$ of $\mathrm{Na}_{2} \mathrm{CO}_{3}(0.1 \mathrm{~mol})$ and $\mathrm{NaOH}(0.35 \mathrm{~mol})$ was prepared. The first solution was slowly added to the second. The resulting mixture was heated at $338 \mathrm{~K}$ under autogeneous pressure for $18 \mathrm{~h}$. After the heating period, the slurry was cooled to room temperature, washed with deionized water up to $\mathrm{pH} \approx 9$ and dried at $383 \mathrm{~K}$ for $18 \mathrm{~h}$. Hydrotalcites were activated by calcination at a rate of $2{ }^{\circ} \mathrm{C} / \mathrm{min}$ until $773 \mathrm{~K}$ and maintained for $2 \mathrm{~h}$ in a flow of air. Later on, samples were cooled in dry nitrogen and stored.

\section{General procedure for the preparation of azidohydrin derivatives}

In a typical experiment, a suspension of $200 \mathrm{mg}$ of calcined hydrotalcite in n-heptane (5ml) was treated with $360 \mathrm{mg}(2 \mathrm{mmol})$ of glycidyl-4-methoxyphenyl ether and $0.530 \mathrm{ml}(4 \mathrm{mmol})$ of trimethylsilyl azide. The suspension mixture was stirred at room temperature for $18 \mathrm{~h}$. The product was obtained after filtration of the catalyst followed by the removal of solvent under reduced pressure affording solely $\mathbf{2 f}$ in the form of a colorless liquid (280 mg, 95\%).

(3-Azido-1-phenylpropan-2-yloxy)trimethylsilane (2c). IR ( $\left.\mathrm{CHCl}_{3}\right)$ 2597, 2098, 1284, 1246, 1105, 969, $844 \mathrm{~cm}^{-1} .{ }^{1} \mathrm{H}$ NMR (300 MHz, $\left.\mathrm{CDCl}_{3}\right): \delta 0.12$ (s, 9H), $2.73(\mathrm{dd}, \mathrm{J}=6,13.2 \mathrm{~Hz}, 1 \mathrm{H}$ ), 2.78 (dd, $\mathrm{J}=$ 6, $13.2 \mathrm{~Hz}, 1 \mathrm{H}$ ), 3.12 (dd, $\mathrm{J}=$ 6, $12.3 \mathrm{~Hz}, 1 \mathrm{H}$ ), 3.18 (dd, J = 4.5, $12.3 \mathrm{~Hz}, 1 \mathrm{H}$ ), 3.94 (qd, J = 4.5, $6 \mathrm{~Hz}, 1 \mathrm{H}), 7.12-7.3(\mathrm{~m}, 5 \mathrm{H}) ;{ }^{13} \mathrm{C}$ NMR $\left(75 \mathrm{MHz}, \mathrm{CDCl}_{3}\right): \delta-0.2$ (q), 41.7 (t), 56.1 (t), 73.1 (d), 126.5 (d), 128.4 (d), 129.6 (d), 137.8 (s).

(2-Azido-1-phenylethoxy)trimethylsilane (2d). IR $\left(\mathrm{CHCl}_{3}\right)$ 2951, 2097, 1253, 1108, 888, $753 \mathrm{~cm}^{-1}{ }^{1} \mathrm{H}$ NMR (300 MHz, CDCl $): \delta \delta 0.12$ (s, 9H), 3.11 (dd, J = 12.6, $3.9 \mathrm{~Hz}, 1 \mathrm{H}$ ), 3.38 (dd, J = 8.4, $12.6 \mathrm{~Hz}, 1 \mathrm{H}), 4.6$ (dd, J = 3.9, $8.4 \mathrm{~Hz}, 1 \mathrm{H}), 7.33$ (m, 5H).

(3-Azido-1-phenoxypropan-2-yloxy)trimethylsilane (2e). IR ( $\left.\mathrm{CHCl}_{3}\right)$ 2597, 2097, 1598, 1496, 1248, 1055, $845 \mathrm{~cm}^{-1} .{ }^{1} \mathrm{H}$ NMR (300 MHz, $\mathrm{CDCl}_{3}$ ): $\delta 0.2$ (s, 9H), 3.33 (dd, J = 12.6, $6 \mathrm{~Hz}, 1 \mathrm{H}$ ), 3.41 (dd, J = 12.6, $3.6 \mathrm{~Hz}, 1 \mathrm{H}), 3.92(\mathrm{~d}, \mathrm{~J}=6 \mathrm{~Hz}, 2 \mathrm{H}), 4.17$ (qd, J = 6, $3.9 \mathrm{~Hz}, 1 \mathrm{H}), 6.88(\mathrm{~m}, 2 \mathrm{H})$, 6.95 (tt, J = 7.5, $0.9 \mathrm{~Hz}, 1 \mathrm{H}), 7.28(\mathrm{~m}, 2 \mathrm{H}) ;{ }^{13} \mathrm{C} \mathrm{NMR}\left(75 \mathrm{MHz}, \mathrm{CDCl}_{3}\right): \delta 0.1(\mathrm{q}), 54.1(\mathrm{t}), 69.2$ (t), 70.4 (d), 114.4 (d), 121.1 (d), 129.5 (d), 158.3 (s).

(1-(4-Methoxyphenoxy)-3-azidopropan-2-yloxy)trimethylsilane (2f). IR $\left(\mathrm{CHCl}_{3}\right)$ 2957, 2099, 1507, 1280, 1241, 1057, $845 \mathrm{~cm}^{-1} .{ }^{1} \mathrm{H}$ NMR $\left(300 \mathrm{MHz}, \mathrm{CDCl}_{3}\right): \delta 0.21$ (s, 9H), 3.34 (dd, J = 12.6, $6 \mathrm{~Hz}, 1 \mathrm{H}$ ), 3.42 (dd, J = 12.6, 4 Hz, 1H), 3.78 (s, 3H), 3.88 (d, J = 6 Hz, 2H), 4.16 (tdd, J = 
6, 6, $4 \mathrm{~Hz}, 1 \mathrm{H}), 6.83(\mathrm{~s}, 4 \mathrm{H}) ;{ }^{13} \mathrm{C}$ NMR (75 MHz, $\left.\mathrm{CDCl}_{3}\right): \delta 0.1$ (q), 54.2 (t), 55.7 (q), 69.9 (t), 70.5 (d), 114.7 (d), 115.3 (d), 152.6 (s), 154.1 (s).

(2-Azido-2-phenylethoxy)trimethylsilane (3d). IR $\left(\mathrm{CHCl}_{3}\right)$ 2975, 2103, 1251, 1121, 851, $721 \mathrm{~cm}^{-1} .{ }^{1} \mathrm{H}$ NMR (300 MHz, $\mathrm{CDCl}_{3}$ ): $\delta 0.12$ (s, 9H), 3.73 (dd, J = 10.8, $8.4 \mathrm{~Hz}, 1 \mathrm{H}$ ), 3.79 (dd, J = 10.8, 4.2 $\mathrm{Hz}, 1 \mathrm{H}), 4.60$ (dd, J = 8.4, $4.2 \mathrm{~Hz}, 1 \mathrm{H}), 7.33(\mathrm{~m}, 5 \mathrm{H}) ;{ }^{13} \mathrm{C} \mathrm{NMR}\left(75 \mathrm{MHz}, \mathrm{CDCl}_{3}\right): \delta-0.6(\mathrm{q})$, 67.3 (d), 67.4 (t), 127.0 (d), 128.3 (d), 128.6 (d), 136.8 (s).

(2-Azidocyclohexyloxy)trimethylsilane (5). IR $\left(\mathrm{CHCl}_{3}\right)$ 2957, 2102, 1597, 1447, 1248, 1103, 839, $743 \mathrm{~cm}^{-1} .{ }^{1} \mathrm{H}$ NMR (300 MHz, $\left.\mathrm{CDCl}_{3}\right): \delta 0.17$ (s, 9H), 1.15-1.40 (m, 4H), 1.64-1.74 (m, 2H), 1.82-1.98 (m, 2H), 3.18 (ddd, $\mathrm{J}=11.1,8.7,4.5 \mathrm{~Hz}, 1 \mathrm{H}$ ), 3.43 (ddd, $\mathrm{J}=10.2$, 8.7, 4.5, $1 \mathrm{H}$ ); ${ }^{13} \mathrm{C}$ NMR $\left(75 \mathrm{MHz}, \mathrm{CDCl}_{3}\right): \delta 0.1(\mathrm{q}), 23.9(\mathrm{t}), 24.2(\mathrm{t}), 30.5(\mathrm{t}), 34.7(\mathrm{t}), 66.8(\mathrm{~d}), 75.3(\mathrm{~d})$. [2a + 3a] IR $\left(\mathrm{CHCl}_{3}\right)$ 2963, 2871, 1459, 1255, 1121, 1046, 842, $750 \mathrm{~cm}^{-1}$. The GC-MS spectrum of the mixture showed two peaks with retention times of 6.53 minutes and 6.64 minutes. The mass spectrum of the first peak is in agreement with structure 2a. CIMS: $\mathrm{m} / \mathrm{z} 188(\mathrm{M}+1)^{+}, 172$ $\left(\mathrm{M}-\mathrm{CH}_{3}\right)^{+}, 145\left(\mathrm{M}-\mathrm{N}_{3}\right)^{+}, 131\left(\mathrm{M}-\mathrm{CH}_{2} \mathrm{~N}_{3}\right)^{+}$. The mass spectrum of the second peak is in agreement with structure 3a CIMS: $\mathrm{m} / \mathrm{z} 188(\mathrm{M}+1)^{+}, 172\left(\mathrm{M}-\mathrm{CH}_{3}\right)^{+}, 145\left(\mathrm{M}-\mathrm{N}_{3}\right)^{+}, 103(\mathrm{M}-$ $\left.\mathrm{CH}\left(\mathrm{N}_{3}\right)\left(\mathrm{CH}_{2}\right)_{3} \mathrm{CH}_{3}\right)^{+}$.

[2b + 3b] IR $\left(\mathrm{CHCl}_{3}\right)$ 2958, 2098, 1459, 1250, 1099, 960, 836, $750 \mathrm{~cm}^{-1}$. The GC-MS spectrum of the mixture showed two peaks with retention times of 12.79 minutes and 12.98 minutes. The mass spectrum of the first peak is in agreement with structure 2a. CIMS: $\mathrm{m} / \mathrm{z} 216(\mathrm{M}+1)^{+}, 200$ $\left(\mathrm{M}-\mathrm{CH}_{3}\right)^{+}, 173\left(\mathrm{M}-\mathrm{N}_{3}\right)^{+}, 159\left(\mathrm{M}-\mathrm{CH}_{2} \mathrm{~N}_{3}\right)^{+}$. The mass spectrum of the second peak is in agreement with structure 3a CIMS: m/z $216(\mathrm{M}+1)^{+}, 200\left(\mathrm{M}-\mathrm{CH}_{3}\right)^{+}, 173\left(\mathrm{M}-\mathrm{N}_{3}\right)^{+}, 103(\mathrm{M}-$ $\left.\mathrm{CH}\left(\mathrm{N}_{3}\right) \mathrm{CH}_{2} \mathrm{CH}_{3}\right)^{+}$.

\section{Acknowledgements}

The authors are indebted to Consejo Nacional de Ciencia y Tecnología (CONACyT) for partial financial support (Project No 33366-E). Messrs, A. Acosta and G. Salcedo for their technical assistance.

\section{References}

1. Cavani, F.; Trifiro, F.; Vaccari, A. Catal. Today 1991, 11, 173.

2. Koteswara Rao, K.; Gravelle, M.; Valente, J.; Figueras, F. J. Catal. 1998, 173, 115.

3. Roelofs, J. C. A. A.; van Dillen, A. J.; de Jong, K. P. Catal. Today 2000, 60, 297.

4. Suzuki, E.; Ono, Y. Bull. Chem. Soc. Jpn. 1998, 61, 1008.

5. Suzuki, E.; Okamoto, M.; Ono, Y. J. Mol. Catal. 1990, 61, 283.

6. Cativiela, C.; Figueras, F.; Garcia, J. I.; Mayoral, J. A.; Zurbano, M. M. Synth. Commun. 1995, 25, 1745. 
7. Cativiela, C.; Figueras, F.; Fraile, J. M.; Garcia, J. I.; Mayoral, J. A. Tetrahedron Lett. 1995, 36, 4125.

8. Climent, M. J.; Corma, A.; Iborra, S.; Primo, J. J. Catal. 1995, 151, 60.

9. See: Mitsunobu O. In Comprehensive Organic Synthesis, Trost, B. M.; Fleming, I. Eds.; Pergamon Press: Oxford, 1991; Vol. 6, pp 4.

10. Tamami, B.; Mahdavi, H. Tetrahedron Letters 2001, 42, 8721.

11. Fujiwara, M.; Tanaka, M.; Baba, A.; Ando, H.; Souma, Y. Tetrahedron Letters 1995, 36, 4849.

12. M. Lakshmi Kantam, M.; Kavita, B.; Rahman, A.; Sateesh, M. Indian Journal of Chemistry 1998, 37B, 1039.

13. Reichle, W. T. J. Catal. 1985, 94, 547. 